Provided for non-commercial research and education use. Not for reproduction, distribution or commercial use.

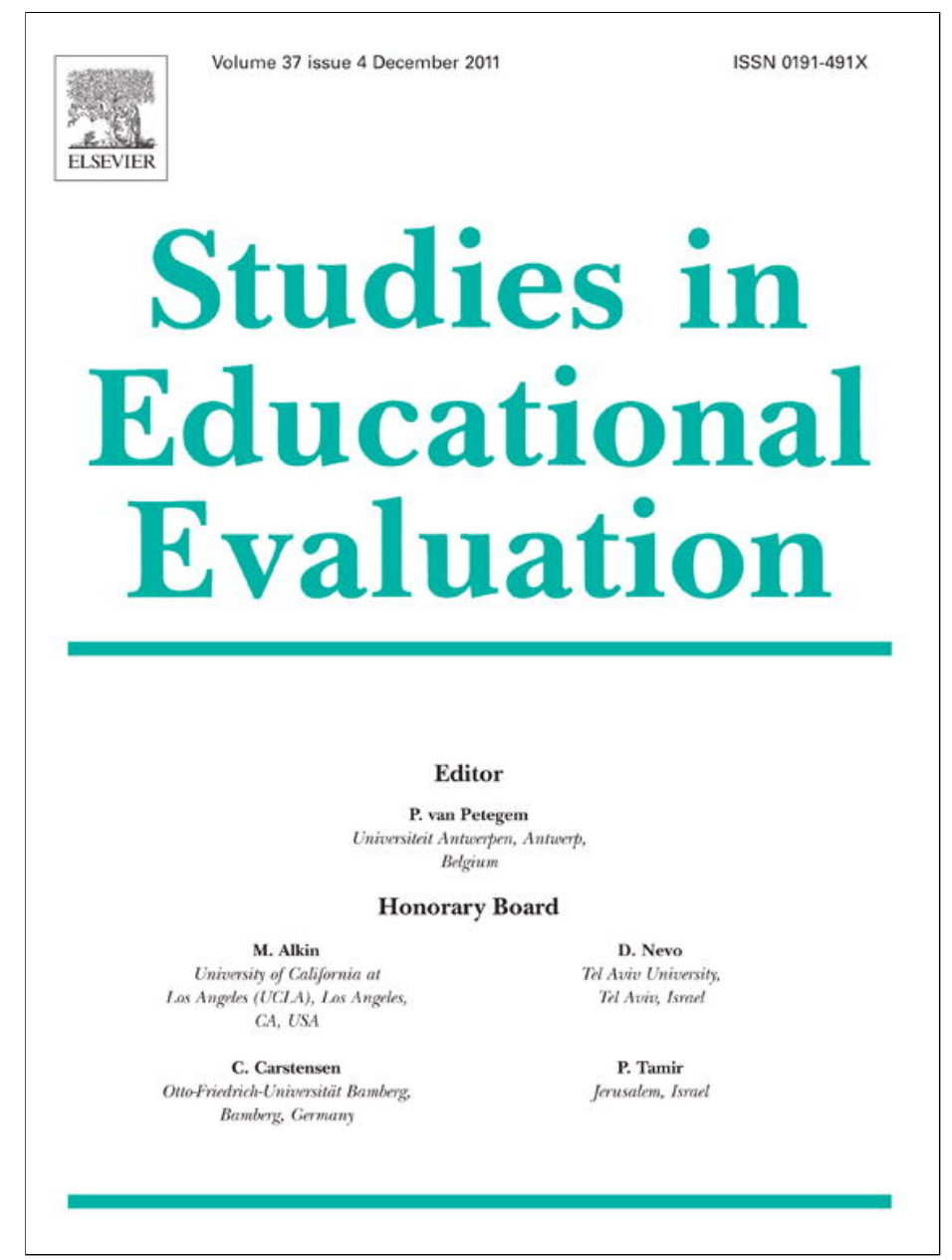

This article appeared in a journal published by Elsevier. The attached copy is furnished to the author for internal non-commercial research and education use, including for instruction at the authors institution and sharing with colleagues.

Other uses, including reproduction and distribution, or selling or licensing copies, or posting to personal, institutional or third party websites are prohibited.

In most cases authors are permitted to post their version of the article (e.g. in Word or Tex form) to their personal website or institutional repository. Authors requiring further information regarding Elsevier's archiving and manuscript policies are encouraged to visit:

http://www.elsevier.com/copyright 


\title{
Risk-based school inspections in the Netherlands: A critical reflection on intended effects and causal mechanisms
}

\author{
M.C.M. Ehren ${ }^{\text {a,* }}$, M.E. Honingh ${ }^{\mathrm{b}}$ \\ ${ }^{a}$ University of Twente, Faculty of Behavioral Sciences, P.O. Box 217, 7500 AE Enschede, The Netherlands \\ ${ }^{\mathrm{b}}$ Radboud Universiteit Nijmegen, Nijmegen School of Management, P.O. Box 9108, 6500 HK Nijmegen, The Netherlands
}

\section{A R T I C L E I N F O}

\section{Article history:}

Received 1 May 2011

Received in revised form 20 December 2011

Accepted 17 February 2012

Available online 28 March 2012

\section{Keywords:}

Accountability

School inspections

External evaluation

Good governance

\begin{abstract}
A B S T R A C T
This paper compares and contrasts the program theory of the reenacted Supervision Act to the Supervision Act of 2003. We describe how the expectations about how schools should be inspected, the effect such inspections are expected to have, and how these effects should be realized have changed over the past years as a result of changing paradigms of governance and the supervision of schools. An ex ante evaluation of the program theory shows that the changed inspection methods are likely to be less effective compared to the previous paradigm.
\end{abstract}

(c) 2012 Elsevier Ltd. All rights reserved.

\section{Introduction}

Many countries across the world arrange for external evaluation of their schools in order to inspect and improve the quality of education. In Europe, the dominant arrangement for external evaluations is school inspection. Inspectorates of Education assess the quality of education in schools, using standards and procedures to evaluate a broad range of goals related to student achievement, teaching, the school organization and leadership (e.g. McNamara \& O'Hara, 2008). They set expectations for performance of schools, they produce evidence as to whether these expectations have been met and expect this evidence to stimulate and orient school improvement.

The Dutch Inspectorate of Education, established in 1801, is one of the oldest operating Inspectorates in Europe. Its working methods, like those of other inspectorates, have evolved greatly over time, particularly in the last decade (de Wolf, 2007; Kerseboom et al., 2007). Neither the Netherlands nor the field of education is alone in this trend as many inspectorates in a number of countries face comparable challenges that stem from current policy directions (Black \& Baldwin, 2010).

One of the historical hallmarks of the Dutch Education Inspectorate, and the starting point of our analysis, is the implementation of the Dutch Educational Supervision Act in 2003. This Act specified the framework for inspection and the

\footnotetext{
* Corresponding author.

E-mail address: m.c.m.ehren@utwente.nl (M.C.M. Ehren).
}

standards the Inspectorate should use in the evaluation of schools (e.g. pedagogical climate and number of lesson hours). The act was implemented to give the Inspectorate of Education a stronger legal foundation for their work in schools and to increase the transparency of their work in an era of increased autonomy of schools.

Moreover, the act revealed that the task of the education inspectorate was at least twofold. The inspectorate had to guarantee that schools comply with legal requirements to ensure the legitimacy of the received state funding. Secondly, the inspectorate had to stimulate and challenge schools to provide a satisfactory level of educational quality and to increase their added value in terms of student achievement. Consequently, the inspectorate had to combine a compliance approach rooted in legal requirements with an approach rooted in stimulating and challenging schools to improve.

Since the Educational Supervision Act came into force in 2003, the political and economic situation as well as expectations toward external inspectorates, control and accountability have changed dramatically. Helderman and Honingh (2009) analyzed Dutch whitepapers on regulation that had been published since 1998 and noticed a stronger emphasis on effectiveness that could be understood as an element of a government-wide drive to reduce the overall administrative burden. One of the attempts to reduce the inspection burden, which could already be found in the Educational Supervision Act, is the notion of proportional inspection that implies a linkage between internal and external control and quality assurance systems. If external supervisors could make use of internal assurance systems such as certification, 
quality contracts and benchmarks, they would be able to arrange for meta-supervision, auditing or other distant forms of inspections (Ambtelijke Commissie Toezicht II, 2005). In line with this reasoning, inspectorates were encouraged and expected to apply methods that were considered more cost efficient such as riskanalysis and risk-calculation. After the government agreed on the use of risk-analysis in 2007 the Inspectorate of Education no longer has to provide for full regular inspections of all schools. Instead, the role of the Inspectorate becomes more complementary to the mechanisms and processes the school board is required to have in place to monitor and improve the education in their schools (e.g. Janssens \& de Wolf, 2009). As the new inspection methods should be aligned to the explicit responsibility of school boards for the quality of education and compliance to the legislation in their schools (where the principal is responsible for the daily operation of the school within the framework set by the school board), the communication between the Inspectorate and the school is with the school board instead of with the principal.

As some of these changes in working methods since 2003 did not fit the 2003 Supervision Act anymore, the law was amended in 2011. This change in legislation calls for a renewed description and reevaluation of the functions and methods of the Dutch Inspectorate of Education. Taking the reconstructed program theory of the 2003 Dutch Supervision Act by Ehren et al. (2005) as our starting point we will compare and contrast the then valid assumptions of how school inspections were supposed to work and the effects they were expected to have with the current assumptions. For the sake of consistency we will build on methods applied by Ehren et al. (2005) to reconstruct the program theory and to analyze how this renewed program theory is different from the former one. Previous work of Janssens and de Wolf (2009) and de Wolf and Verkroost (2010), who have reconstructed assumptions of changes in policy on the governance and control of schools by the Department of Education in general, will inform our analysis in so far as they address how inspection methods (within that context) area expected to lead to school improvement. Available research on effects of school inspections will be used to discuss the validity and realism of the renewed program theory in comparison to the former one. The comparative take will help to answer the following questions:

\section{- How are school inspections currently expected to lead to good education?}

- How are these assumptions different from the assumptions that were stated in 2003 and what shift in inspection paradigm can be found?

- How are the old and new inspection paradigms different and which paradigm is expected to be most realistic in promoting good education?

The next section outlines the method to reconstruct and evaluate the program theory.

\section{Method}

In this paper we will reconstruct the program theory of the reenacted Supervision Act of 2011. A program theory is 'an explicit theory or model of how a program causes the intended or observed outcomes' (Rogers et al., 2000, p. 5). Identifying and explicating a program theory enables us to evaluate the validity of the assumptions and expose potential implementation and theory failures. Implementation failures arise when intended activities are not put into operation (Weiss, 1997); they can be identified in an ex post evaluation when the actual implementation of the program is evaluated in comparison to its intended implementation. In this paper we will focus on potential theory failures and use the reconstruction of the renewed Supervision Act as an ex ante evaluation. Such an ex ante evaluation discusses the validity and coherence of the assumptions and builds on previous research findings to discuss the realism of the propositions. An ex ante evaluation enables us to point out the potential impoverished nature of the theory that underlies the current approach of school inspections and the rationale for changing this approach.

As we will compare and contrast the program theory of the reenacted Supervision Act of 2011 to the Supervision Act of 2003, we will lean on the choices Ehren et al. (2005) made in the reconstruction of the 2003 Supervision Act. Ehren et al. (2005) chose a policy scientific approach to reconstruct their program theory. A policy scientific approach is described by Leeuw (2003) as one that is strongly linked to mainstream evaluation methods and uses interviews, documents to reconstruct the assumptions underlying a program; an argumentative analysis is used to distinguish relevant statements from these documents and interviews and rephrase them into assumptions describing causal mechanisms. The benefit of this approach is the use of evidence to reconstruct a consistent program theory (Karstanje, 1996). Other methods, such as a strategic assessment approach which includes group dynamics and dialog to empower stakeholders to share knowledge and perspectives, or the elicitation methodology where mental models and cognitive maps of members of organizations are extracted to explain and predict organizational outcomes, run the risk of negotiating the informative and empirical content of the program theory or including ideological or politically correct statements about the content of the program theory (Leeuw, 2003). Ehren et al. (2005, p. 61) outline the steps that are taken when using a policy scientific approach to reconstruct a program theory. These steps will also be taken to analyze documents to reconstruct the program theory of the reenacted Supervision Act of 2011:

1. Identify the social and behavioral mechanisms that are expected to solve the problem; search formal and informal documents for statements indicating the necessity of solving the social, organizational, or policy problem in question, the goals of the proposed policy or program, and how they are to be achieved. These latter statements refer to mechanisms (or "engines") that drive the policies or programs and are believed to make them effective. Examples are manifold. They include determinants of innovation diffusion, mechanisms underlying Prisoner's Dilemma games, processes producing social capital, cognitive dissonance, different types of learning behavior, and many more. Statements having the following form are especially relevant for detecting these mechanisms:

- It is evident that $x$ will work.

- In our opinion, the best way to address this problem is to.

- The only way to solve this problem is to.

- Our institution's $x$ years of experience tell us that.

2. Compile a survey of these statements and link the mechanisms to the goals of the program under review.

3. Reformulate the statements into conditional "if-then" propositions or propositions of a similar structure (e.g., "the more $x$, the less $\left.y^{\prime \prime}\right)$.

4. Search for warrants that will identify disconnects in or among different propositions using argumentation analysis. Founded in part on Toulmin's (1964) The Use of Argument, argumentation analysis refers to a model for analyzing chains of arguments and helps to reconstruct and "fill in" argumentations. A central concept is the warrant, which, according to Toulmin (1958) and Mason and Mitroff (1981), is the "because" part of an argument. A warrant says that B follows from A because of a (generally) accepted principle. For example, “the organization's 
performance will not improve next year" follows from "the performance of this organization has not improved during the past 5 years" because of the principle that past performance is the best predictor of future performance. The "because" part of such an argument is often left implicit, with the consequence that warrants must be inferred by the person performing the analysis.

5. Reformulate these warrants in terms of conditional "if-then" (or similar) propositions and draw a chart of the (mostly causal) links.

The starting point of the reconstruction of the reenacted Supervision Act is a whitepaper on supervision and regulation (Department of Internal Affairs, 2005) in which principles of good supervision and regulation were presented. This whitepaper introduces a number of starting points for (school) inspections. These starting points are elaborated in additional documents of both the Department of Education and the Inspectorate of Education, such as the 'Governance letter' (2005), and the policy document 'trustworthy inspections' (2006). The evaluation of the Supervision Act in 2007 outlines additional changes that lead to the reenactment of the Supervision Act. Smeets and Verkroost (2011) describe a time line of documents that were produced from the implementation of the first Supervision Act up to the reenactment of the Supervision Act. All these documents were analyzed according to the steps described above. We also analyzed newsletters of the Inspectorate of Education, describing changes to the Supervision Act and their intended outcomes, minutes of discussions in parliament about the reenactment of the Supervision Act, the final outline of the revisions of the Supervision Act and the memorandum of understanding, explaining the rationale for the reenactment of the Supervision Act. Additionally, we studied two papers in which assumptions of the new inspection methodology and the broader theory of action of the Department of Education on governing and controlling schools was reconstructed by employees of the Inspectorate of Education who were involved in developing the new inspection methods (de Wolf and Verkroost, 2010; Janssens and de Wolf, 2009).

The reconstruction of the program theory also included a participant check were five employees of the Inspectorate of Education and four policymakers of the Department of Education were asked to indicate whether the assumptions in the reconstruction of our program theory provide an accurate description of the new inspection methods and their intended effects. The participant check with Inspectorate employees included individual exchanges, whereas a meeting with a group of four policymakers of the Department of Education was used to discuss the validity of the assumptions. Both employees of the Inspectorate and the Department of Education were actively involved in outlining changes to the Supervision Act and in designing and implementing the risk-based school inspections; they could therefore adequately reflect on the accuracy of the assumptions.

We considered a total number of nine members for the participant check as an adequate quantity to validate our program theory as the comments and proposed changes to the assumptions given by these participants were overall relatively similar and agreement was reached on the final (revised) assumptions by the majority of the participants. Revisions to the assumptions included the inclusion of the four yearly school visits and the (changes in the) publication of findings in the reconstructed theory to describe the full range of inspection methods. Furthermore, it turned out to be necessary to analyze a number of additional documents related to the legislative changes of good governance in schools to elaborate on the assumptions related to the communication to the school boards and to be able to describe the broader context in which the Inspectorate operates.
After reconstructing the current program theory we compared and contrasted it to the previous one, specifically outlining changes in functions and intended effects, inspection activities and mechanisms. We will discuss the extent to which these changes are expected to lead to more effective school inspections in terms of achieving the intended goals of promoting minimum student achievement results. Our choice of literature to evaluate these assumptions is informed by recent scientific research on selfregulation, polycentric steering and regulation. These concepts are at the heart of current debates in public administration and provide a suitable knowledge base to contrast and discuss the program theory.

\section{Results}

This section presents the evaluation of the Supervision Act of 2003 and the recently amended Supervision Act. We start with a description of the motives that led to the first Supervision Act in 2003 and the reconstructed program theory of this Supervision Act by Ehren et al. (2005). Their reconstruction describes the functions and intended effects (1), inspection activities (2) and mechanisms (3) that were foreseen in the first Supervision Act. In the second part of this section we will present our reconstruction of the program theory of the amended Supervision Act and changes that led to these amendments following the same approach and structure of Ehren et al. (2005). Here, it is important to mention that developments and adjoining legislation that led to changes in the Supervision Act or that affect the working methods of the Inspectorate of Education are also taken into account.

\section{Supervision Act 2003}

In the early 1990s a number of changes took place that ultimately led to the first Supervision Act. School inspections became centrally structured, well outlined and publicly discussed evaluations of schools, instead of evaluations that varied according to the background, personal views on the role of school inspections and agenda of every individual school inspector (Elte and Scholtes, 2001). School inspectors started to evaluate schools using standardized frameworks, procedures and protocols. During that period, a need was felt to include these frameworks, procedures and protocols in new legislation to secure the position and working methods of the Inspectorate of Education and to enhance the transparency of their work.

\section{Functions and intended effects of school inspections}

In the process of developing standardized frameworks, procedures and protocols, the Inspectorate tried to involve different opinions and definitions of educational quality of central and local governments and of schools (Elte, 2002). According to Elte (2002), the Inspectorate ultimately chose to frame its function as contributing to societal trust in public education and to guarantee that schools deliver a satisfactory level of educational quality for all citizens. Guaranteeing educational quality is, according to the memorandum of understanding of the Supervision Act, achieved primarily through inspection of legal requirements that schools should comply with.

According to Ehren (2006), these legal requirements were, however, considered to be insufficient for achieving the goals of improved education. The Educational Supervision Act therefore further specified quality standards (that partly elaborate on the legal requirements). The Inspectorate was entitled to evaluate these quality standards in such a manner that schools are stimulated to provide higher standards of quality than those 
considered merely satisfactory. These quality standards represent, according to the memorandum of understanding (p. 11), the aspects of performance of schools considered important by the legislator. Schools were however not obliged to meet these quality standards; they only have to comply with legal requirements. However, schools are seen as organizations that are willing to change and inspections of these quality standards were therefore expected to stimulate schools to aim for high educational quality, within their own school goals and mission. High educational quality is defined as the added value of schools in terms of student achievement.

2. Inspection activities

The reconstructed program theory by Ehren et al. (2005) describes three activities through which school inspections are expected to lead to increased added value of schools: quality assessments of legal requirements and quality standards (part of an overall framework), the publication of findings and proportional inspections.

\section{Quality assessment}

As Ehren et al. (2005, p. 5/6) describe, "the framework used by the inspectorate to assess school quality integrates two types of indicators: legal requirements and quality standards. Legal requirements are formulated in the separate educational acts. Schools have to meet these requirements to receive governmental financing. These requirements describe, for example, a number of educational goals or state that schools should prepare their pupils for secondary education. Quality standards, such as an adequate pedagogical climate and supply of subject matter, are part of the Educational Supervision Act and are intended to guide the inspectorate in assessing schools. Schools are not obliged to meet these criteria."

The Educational Supervision Act assumes that school inspectors provide feedback to schools on their strengths and weaknesses including suggestions on how to improve related to these quality aspects and legal requirements. Schools assessed by inspectors as 'failing schools' should be visited more intensively and more frequently than other schools, and inspectors should draw up written agreements with these schools about the improvements required. In this case, over and above its evaluative role, the Inspectorate should also fulfill an advisory function for weaker schools, specifying possible improvements and explaining how things can be done differently. Schools may also be requested to describe how they will attempt to implement the school improvement action plan and these plans should be monitored thereafter by the school inspector.

\section{Publication of findings}

The publication of inspection findings was, according to Ehren et al. (2005), also expected to stimulate schools to improve. The Inspectorate of Education publishes assessments of individual schools in so called quality cards on the Internet. These quality cards include an overview of how the school is doing on each standard in the inspection framework. The extensive written inspection report of individual schools was also published on the Internet.

\section{Proportional inspection}

Finally, the Supervision Act arranges for proportional inspections of schools. According to Ehren et al. (2005, p. 66), the proportional working method of inspection describes the use of results of quality assurance and self-evaluation of schools by the Inspectorate to form judgments about school quality. To be helpful, the self-evaluation results of schools must be reliable and provide information about the indicators included in the inspection framework. If these requirements are met, the Inspectorate will confront the schools with fewer and less intense inspection visits and request less information from schools to inform inspection assessments.

\section{Mechanisms}

The program theory of the Supervision Act, as reconstructed by Ehren et al. (2005) specified expectations about how these aspects of school inspections were expected to work and lead to intended effects. Quality assurance and self-evaluation of schools were a first important link between proportional inspections and increased added value of schools. The promise of less intense and frequent inspection visits was expected to motivate schools to engage in self-evaluation activities that would reveal strong and weak aspects of their functioning. Schools were expected to use these insights to improve and, as a result, to increase their added value. The proportional inspection method was also expected to lead to efficient allocation of inspection capacity to failing schools, where failing schools are provided with more feedback to inform their improvement processes. Inspection feedback was expected to be a strong motivator for school improvement.

Finally, the publication of inspection findings was expected to promote some kind of market mechanism where improvement of schools is motivated through informed school choice and voice of parents.

A more detailed description of the program theory of the 2003 Supervision Act can be found in Ehren et al. (2005).

\section{Renewed Supervision Act 2011}

Political and societal developments led to a change in the Dutch Department of Education's philosophy and theory of action on how schools should be controlled and governed. The Dutch Educational council (2006) describes how deregulation of educational policy, increased autonomy and scaling up of school organizations implied a greater need for increased professionalism of school boards and school management. The Department of Education (2007) considered that school autonomy and decentralization could only succeed if school boards increased the professional administration and governance of their schools. A number of legislative changes were initiated to motivate school boards to improve their governance of schools; they were required to arrange for separate mechanisms of the administration and internal supervision of their schools and to develop and implement codes of conduct for good governance. As a result, the system of horizontal checks and balances of professional schools and governance of schools was extended.

Such a change in checks and balances in schools also implies a change in the role for the Inspectorate of Education. External supervision by the Inspectorate of Education should, according to Smeets and Verkroost (2011) and Janssens and de Wolf (2009), act complementary to these horizontal mechanisms by risk-based selective school inspections of underperforming schools. The Inspectorate of Education should also communicate their activities to school boards (instead of principals) and should evaluate the functioning of school boards.

According to the Dutch Educational Council (2006), the societal and political need to have more efficient and effective school inspections with less administrative burden for schools also prompted risk-based inspections. Schools that have no risks of 
failing quality are not scheduled for an inspection visit and will experience less inspection burden.

The Educational Council (2006) and the evaluation of the Supervision Act (Inspectorate of Education, 2010a, 2010b, 2010c, 2010d, 2010e) also point to a number of incidents where the Inspectorate of Education did not have the authority to intervene in systematically failing schools due to the fact that schools are not obliged to improve their functioning on the quality standards. As a result of these incidents, the Inspectorate of Education will be provided with additional options to sanction schools in case of long-term failure. These additional options should enable the Inspectorate, according to the memorandum of understanding of the renewed Supervision Act, to intervene more quickly and more effectively in schools that are underperforming or that fail to comply with legislation.

\section{Functions and intended effects of school inspections}

The Memorandum of understanding of the revised Supervision Act (2009, p. 9) describes how the risk-based inspection method changes the role of the Inspectorate into one of examiner, auditor and enforcer. The Inspectorate now assesses whether schools meet requirements and offer a minimum quality level; guaranteeing a satisfactory level of education is now the central function of school inspections (Educational Council, 2006). School inspections are expected to lead to good education which is described in the annual working document of the Inspectorate (2010) as 'ensuring that all students have the opportunity to achieve their academic potential'. The effects of school inspections can, according to the Department of Education (2007), be determined by looking at the percentage of (highly) failing schools and the average assessments of schools on the inspection standards, as well as the extent to which schools comply with legislation and meet requirements of financial lawfulness. An important indicator in defining a satisfactory level of education is, according to the Educational Council (2006), student achievement results.

2. Inspection activities

The precise nature of inspection at the level of schools varies depending on the outcome of the initial risk-based analysis (Department of Education, 2007). Nevertheless, the Inspectorate of Education continues to use an inspection framework to assess schools after the reenactment of the Supervision Act. The riskbased school inspections are now the primary method of implementing proportional inspections and the Inspectorate publishes the results of these analyses on the Internet. The description of these activities below clearly illustrates that the working methods of the Inspectorate have changed.

\section{Quality assessment}

The Inspectorate of Education continues using an inspection framework to assess schools after the renewal of the Supervision Act (Inspectorate of Education, 2010a). In addition to evaluating the quality standards and legal requirements, the Inspectorate is also given the assignment to evaluate the quality of teaching personnel, the quality of governance of schools and financial lawfulness. Additional legislation of 'Good Education Good Governance' (Inspectorate of Education, 2010b) also outlines minimum student achievement results as legal requirements schools have to meet to prevent being sanctioned.

\section{Proportional inspections}

The Inspectorate of Education uses the method of risk-based school inspections to evaluate schools' performance on the inspection framework. The Inspectorate carries out early warning analyses, using information on possible risks of low educational quality in schools, such as student achievement results on standardized tests and school documents. The student achievement results are expected to predict performance of schools on all the standards in the inspection framework (Inspectorate of Education, 2009a). Schools with no risks are not scheduled for inspection visits, whereas schools that show risks receive additional inspection monitoring and interventions.

Additional monitoring includes desk research of additional results and school documents (for example, test scores in intermediate grades or annual reports), interviews with the school board and potentially also inspection visits where the inspection framework is used to assess educational quality in the school as sufficient, failing or highly underdeveloped (Inspectorate of Education, 2009b)

Failing or highly underdeveloped schools are scheduled for additional interventions; the school board has to formulate a plan of approach aimed at improving quality. The inspectorate monitors the implementation of this plan. In case the school does not improve, sanctions may be enacted such as official warnings or administrative and/or financial sanctions (Inspectorate of Education, 2009b).

The inspection activities and potential interventions in schools are now communicated to the school board (instead of the principal). Also, some of the data collection on educational quality of schools is carried out through interviews and surveys given to school boards (Inspectorate of Education, 2010a).

In addition, the House of Representatives of the States General agreed in October 2007 to add a provision of four yearly visits to the risk-based school inspections. All schools in primary and secondary education (also high quality schools) should be visited by the Inspectorate of Education at least once every four years. These visits are instated to provide for a 'reality check' and to prevent schools from having no inspection visit for a long period of time (Inspectorate of Education, 2010c). The visit is however explicitly not instated to evaluate schools on all the standards in the inspection framework, but only on a selection of standards that is relevant given the previous results of the early warning analysis of the school or the agenda of the Inspectorate.

\section{Publication of inspection findings}

After the implementation of risk-based school inspections, the Inspectorate cannot publish quality cards anymore as only a minority of schools are evaluated on all inspection standards (only schools with potential risks of failing). As a result, only the type of activity/visit assigned to schools was published, as well as reports of inspection visits of potentially failing schools, and a list of failing and underdeveloped schools (Department of Education, 2007).

\section{Mechanisms}

The renewal of the Supervision Act, and the changes in inspection methods, are expected to lead to more effective school inspections that contribute directly to improvement of educational quality in schools, and also indirectly stimulate quality development of schools (see Department of Education, 2007, pp. 2-3; Inspectorate of Education, 2010d, p. 18; Inspectorate of Education, 2010c, p. 3 and Inspectorate of Education, 2010e, p. 19).

In particular, risk-based school inspections are expected to increase effectiveness of school inspections by identifying potentially low performing schools and increasing inspection activities in these schools (and less inspection activities in well performing schools) (Inspectorate of Education, 2010d). 
Increasing inspection activities in potentially failing schools is expected to be more effective than using the same inspection capacity for inspection of all schools. Inspection of potentially failing schools should motivate these schools to quickly bring their educational quality up to par again. The Inspectorate of Education motivates schools to do so by instructing the school board and the school to make necessary improvements and by controlling the outcomes of these improvements. The Inspectorate also motivates failing schools to improve when publishing their name on a list of failing schools on the Internet. The fact that additional sanctions can be enacted also acts as a strong impetus for change. The Inspectorate expects failing schools to quickly improve after an inspection visit as school boards are often not aware of the failure of their schools or of the decline in quality of their schools. Schools and school boards are expected to be very willing to change (Inspectorate of Education, 2010d)

In addition, risk-based inspections are also expected to prevent failure of schools as early identification of potential risks of failing quality should enable speedy interventions in these schools that are expected to prevent a further decline in educational quality (Inspectorate of Education, 2010a, 2010d). Also, school boards are early on informed of potentially failing schools and are expected to take action to improve their schools. The fact that they are required to send in information on the quality of their schools should also motivate them to stay informed on the quality of their schools and to keep working on potential improvements (de Wolf and Verkroost, 2010; Janssens and de Wolf, 2009).

These mechanisms are expected to guarantee a minimum level of quality (in terms of student achievement levels) in schools. Stimulating broader quality development of schools is expected to be taken up by school boards, internal supervisors and stakeholders of the school (see Department of Education, 2007, pp. 2-3; Inspectorate of Education, 2010c, p. 3 and Inspectorate of Education, 2010e, p. 19; Inspectorate of Education, 2010d, p. 18). They are expected to use benchmark information, provided by the Inspectorate, to effectively exert an influence on the strategic choices of schools and motivate improvement of schools (Inspectorate of Education, 2010a). A detailed description of the assumptions can be found in Appendix.

\section{Analysis}

Bringing together the functions and intentions, inspection activities and mechanisms as presented in the results section in Table 1 helps to identify and analyze the changes as well as to summarize the results. With regard to the functions and intended effects we note two shifts. First of all, a minimum level of educational quality is now defined in terms of (minimum) student achievement levels whereas this definition used to focus primarily on compliance of schools with legal requirements. Secondly, stimulating broad quality development is no longer considered to be a task of the Inspectorate of Education, but of school boards, internal supervisors and stakeholders of the school. The Inspectorate should support this function by providing these actors with benchmark information on the school.

The choice of focusing on the guaranteeing function of the Inspectorate instead of stimulating educational quality is prompted by the fact that school inspectors were put into the role of educational advisors where they eventually had to evaluate the outcome of their own advice (Memorandum of Understanding, 2009). This double role was considered to be incompatible with the notion of independent assessment and evaluation.
Looking at the inspection activities, the two most prominent changes are risk-based school inspections and communication of inspection activities to/with school boards (Inspectorate of Education, 2007). In their essay on 'selective and effective school inspections', Smeets and Verkroost (2011) argue how risk-based school inspections are in fact a further elaboration of the idea of proportional inspections as originally described in the Supervision Act. Smeets and Verkroost (2011) state that the self-evaluation results of schools limitedly met the reliability and validity criteria in the Supervision Act. As a consequence proportional inspection led only to some variation in the intensity of inspection visits that ranged from short yearly visits to extensive two day visits once every four years. In the amended Supervision Act, risk-based school inspections are included to foresee an actual variation in frequency of school inspections, in addition to a variation in intensity of school inspections. Well-performing schools are, in the arrangement of risk-based school inspections, not visited. Also, student achievement results are now (in addition to signals, yearly documents and complaints of parents) the central indicator to inform proportional inspections, instead of the quality assurance and self-evaluation results of schools.

The communication of inspection activities to/with school boards aligns with the new philosophy of good governance where school boards are considered the primary actors in governing the quality of their schools and where additional legislative changes require school boards to have an internal supervisory board in place and to provide an account to stakeholders (Inspectorate of Education, 2009a).

With regard to the mechanisms that can be found in Table 1 it becomes clear that the mechanisms the Inspectorate relies on depend largely on the outcome of the risk-analysis. Schools that perform well are considered to be affected indirectly by the Inspectorate and directly by other stakeholders or mechanisms, whereas weaker schools can count on direct motivators and involvement of the Inspectorate. In the 'old' Supervision Act, the Inspectorate of Education was more directly involved in improvement of all schools through regular visits and feedback on potential improvement in all schools.

\section{Conclusion and discussion}

Assumptions underlying inspection methods, inspection paradigms and their contribution to promote good education are at the heart of this paper. The assumptions underlying the Dutch Education Supervision Act were taken as a point of reference to examine the differences in assumptions between the current amended Supervision Act and the former one. The analysis already showed a number of transformations in the underlying assumptions as well as in the working methods of the Inspectorate. In this section we reflect once more on the major shifts that have been made over the last decade with the help of theoretical notions and by indicating whether the changes that have been made offer promising anchor points to the much-wanted educational improvement.

The transformations that become clear from the analysis can in a more abstract sense be presented as a shift from a primarily monocentric form of quality development steering with a broad range of indicators related to educational processes and school outputs, to a more polycentric type of steering with a larger focus on output and performance of schools.

A monocentric form of steering is described by Teisman (1992) as the idea that national government is the central actor in defining and designing society and in deciding on how to tackle societal issues. In a monocentric form of steering, national government focuses on governing 'throughput' of organizations, such as educational and financial/organizational processes in schools 
Table 1

Comparison of Supervision Act 2003 and 2011.

\begin{tabular}{lll}
\hline & Supervision Act 2003 & Amended Supervision Act 2011 \\
\hline Functions and intended effects & Guaranteeing quality in terms of compliance with legal & Guaranteeing quality (primarily) in terms of minimum \\
& requirements & student achievement results \\
& $\begin{array}{l}\text { Stimulating improvement of schools' functioning on quality } \\
\text { aspects and added value of schools (in terms of student }\end{array}$ & Stimulating improved education through providing \\
achievement) & benchark information
\end{tabular}

Inspection activities Quality assessment based on legal requirements and quality aspects

Proportional inspection; using results of quality assurance and self-evaluation to judge schools' quality and determine the reliability of the self-evaluations. Reliable selfevaluation might lead to fewer and less intense inspection visits

Publication of inspection findings of individual schools' functioning on the inspection framework in 'quality cards' and inspection reports on the Internet

Mechanisms

The promise of less intense and frequent inspection visits motivates schools to engage in quality assurance and selfevaluation which should in turn lead to increased added value.

Direct feedback on weak and strong points of schools would lead to improvements.

Proportional inspection would lead to an efficient allocation of inspection capacity to weak schools

Publication of inspection finding was expected to stimulate well-informed school choice and voice of parents
Quality assessment through an evaluation of the legal requirements and quality aspects, the quality of teaching personnel, the quality of governance of schools and financial lawfulness. Minimum student achievements are outlined as legal requirements

Risk-based school inspection based on student achievement results, self- evaluation reports, financial reports, complaints of parents and media items to determine whether inspection visits and research are necessary.

Reality check; a four yearly school-visit to validate the riskbased inspection methodology and allocated inspection activity

Publication of inspection arrangement attributed to schools, a list of failing and underdeveloped schools

Through communication of inspection activities, outcomes and interventions to school boards of failing schools, school improvement is stimulated.

Preventing failure of schools through early identification of potentially failing schools

Risk-based inspections are expected to increase the effectiveness of school inspections by identifying potentially failing schools and increasing inspection activities in these schools (including increased monitoring, instruction to school boards and potential sanctioning of schools)

Publication of a list of weak schools should motivate schools to improve
(Bekkers, 2009). Through instructions, norms, policy guidelines, monitoring, control and inspections, national government tries to influence these processes.

The first version of the Supervision Act in 2003 is highly inspired by this type of monocentric steering. The Act contains a multitude of indicators on throughput of schools, and the Inspectorate of Education (as a representative of the national government) is the primary organization in monitoring schools' functioning on these indicators. The feedback of school inspectors during inspection visits and the requirements on using selfevaluations of schools as part of school inspections are one of the primary central steering mechanisms in governing throughput of schools.

The reenacted Supervision Act of 2011 highlights a more polycentric form of steering where central government (and the Inspectorate of Education) is only one of the actors in governing schools. Steering takes place in a context of interdependent networks of different actors (Teisman, 1992) who use knowledge, information and other resources to influence schools. According to Bekkers (2009), in a polycentric steering arrangement, central government builds on available steering capacity in organizations and in the field to perform some kind of meta-steering and network management. This meta-steering may include the setting of performance indicators of school outputs, instating incentives (such as sanctions) to meet these indicators and structuring relations between different actors in and stakeholders of organizations. The indicators on minimum student achievement results schools must meet and the requirements (laid down in additional legislation of 'Good Education Good Governance') for schools to have an internal advisory board and define codes of good governance fit this type of polycentric meta-steering and network management. The Inspectorate is explicitly placed in this network of polycentric steering when, for example, reducing its role to only guaranteeing minimum educational quality in terms of student achievement in schools, and providing benchmark information to actors in the network around schools.

This change in steering paradigm is expected to increase the effectiveness of school inspections as inspection capacity can be allocated to potentially failing schools and early identification of potentially failing schools should prevent failure of schools. In this section we ask ourselves whether this change in paradigm is actually effective in promoting school improvement.

A first reflection in this respect includes a discussion of how the Inspectorate of Education implements risk analyses to identify schools in need of improvement. Risk-based inspections have been implemented in a wide range of Western countries to manage social problems and potentially dangerous situations (see Black and Baldwin, 2010; Honingh and Helderman, 2010). To identify risks, potential dangers and problems, a wide variety of frameworks have been developed. Risk-analysis frameworks generally include two types of risks (Black and Baldwin, 2010). Firstly, there are inherent risks that arise from the nature of the business's activities. Secondly, there are management and control risks including compliance records. The above definitions illustrate that a risk-analysis can be seen as an indicator of the reliability of an internal control or quality assurance system.

These definitions reveal that the Dutch Inspectorate of Education applies the term risk-analysis in a somewhat deviant and less effective way. To determine whether a school is potentially at risk (a weak school), the school outcome (measured 
through pupils' achievement results) is considered to be a riskindicator. This focus on achievements contrasts with one of the basic ideas of risk analyses to offer warnings, information about potential shortcomings, instability and direct causes of failures (e.g. Honingh \& Helderman, 2010). The choice of student achievement results as the primary risk indicator implies an identification of schools that are already failing. Inadequate teaching and leadership in these schools have led to low student achievement (and not the other way around). Warnings to prevent such failings however need to identify schools before their student achievement results are below average. For example, indicators on internal quality control, self-evaluations, quality of educational processes or other causes of failure (such as substantive changes in student or teacher population) are more suitable to provide such warnings. Such a risk-analysis is better able to actually prevent failing schools and to stimulate learning and the implementation of improvements. Now that the Inspectorate focuses on outcomes, the incentive to improve seems to be less direct and the instruments to prevent schools from becoming a failing school are not present.

Moreover, the change toward a polycentric paradigm is expected to activate other actors to motivate school improvement. Schools should be stimulated to improve on a broad range of indicators through their functioning in a network of actors and arrangements. The major underpinning assumption of such a type of steering seems to be that the accountability and education system has reached a new level of maturity where performance improvement no longer needs to be driven from top down. Instead, school leaders and teachers are expected to have the will and the means to improve education on their own.

Evidence of low evaluation and change capacity of schools however leads us to question whether the current Dutch education system has reached the maturity level that is needed to effectively implement a polycentric steering approach. The annual reports of the Inspectorate of Education and Hooge en Honingh's (2011) report on governance in primary schools show that only a limited number of schools and school boards have implemented structured quality assurance systems; also school boards primarily focus on personnel and financial matters instead of educational quality in schools.
A final remark concerns the fact that the focus on student achievement results as the primary indicator in the risk-analysis implies a move toward a more test-based accountability system. Evidence from the U.S., where test-based accountability is the dominant form of accountability, points to strategic behavior of schools related to measures of student achievement. Koretz (2003) describes different types of undesirable test preparation where schools take classroom time away from important aspects of the curriculum that are not represented in the test (for example, because they are difficult to assess in a multiple choice test format). Teachers were also found to coach pupils to do better by focusing instruction on incidental aspects of the test (such as item format) or spending large amounts of class time on test-taking instruction instead of regular teaching. Because instruction is focused on incidental features, learning about them does not produce real improvements in pupil's knowledge of a certain subject. Undesirable test preparation therefore leads to increased test scores that neither generalize to a second test nor represent meaningful increases in pupils' knowledge of a certain domain (test inflation) (Koretz, 2002).

These critical remarks indicate that the new paradigm of riskbased school inspections in a polycentric context of governance of schools is expected to be less effective than the previous paradigm of inspection visits and feedback to all schools. Potential effectiveness of school inspections is highly dependent on activities of stakeholders in and around the school (such as school boards and internal supervisors), and these stakeholders have so far not taken up their role of controlling and improving educational quality of schools. Additional arrangements, such as support and incentives, seem to be necessary to motivate these stakeholders to stimulate school improvement. Also, using primarily student achievement results to identify potentially failing schools will not enable these stakeholders, or the Inspectorate of Education, to take timely action to prevent failure of schools.

\section{Appendix A. Summary of assumptions}

See Tables A1-A4.

Table A1

Assumptions on risk-based school inspections.

1. If the Inspectorate of Education uses risk-based school inspections, schools will (eventually) offer good education.

1.1. If the Inspectorate of Education uses risk-based school inspections, good schools will be inspected less often, whereas failing schools are inspected more often.

1.2. If good schools are inspected less often, they will experience more freedom to make decisions on their own education.

Because: schools have autonomy to make decisions on how to organize their education, using their own professional insights (the Department of Education only decides on the outcomes they should achieve).

Because: administrating and controlling schools are closely connected. Schools will experience more freedom if they are controlled less often.

1.3. If good schools experience more freedom to make decisions on their own education, they will use this freedom to (maintain or) offer good education. Because: these schools have shown to be capable of providing good education; they can be trusted to make decisions on their education.

1.1. If the Inspectorate of Education uses risk-based school inspections, failing schools are inspected more often.

1.2. If failing schools are inspected more often, they will improve more quickly.

Because: the Inspectorate instructs the school boards of these schools to improve failing indicators within a specified time frame. The Inspectorate also checks the results of these improvements. Schools are motivated to improve through publication of their name on a public list of failing schools and the potential threat of sanctions.

Because: in most cases schools will improve when the Inspectorate addresses potential shortcomings to the school board and makes agreements on potential improvements. School boards often are not aware of the failure of their schools or of the decline in quality of their schools.

1.3. If failing schools improve, they will offer good education.

1.1. If the Inspectorate of Education uses risk-based school inspections, failing schools are inspected more often.

1.2. If failing schools are inspected more often, the Inspectorate will intervene sooner when quality in these schools is declining.

1.3. If the Inspectorate intervenes sooner when quality of schools is declining, the Inspectorate or school boards will prevent these schools from becoming failing or underdeveloped.

Because: in most cases schools will improve when the Inspectorate addresses potential shortcomings to the school board and makes agreements on potential improvements. School boards are often not aware of the failure of their schools or of the decline in quality of their schools.

1.4. If the Inspectorate or school boards prevent schools from becoming failing or underdeveloped, schools will continue to provide good education. 
Table A2

Assumptions on communication to school boards.

2. If the Inspectorate of Education addresses inspection activities to school boards, schools will provide good education.

2.1. If the Inspectorate of Education addresses inspection activities to school boards, school boards will improve their governance of schools (through implementing quality assurance, separate mechanisms for administration and internal supervision of schools and accountability to stakeholders).

Because: the Inspectorate forces school boards to provide information about the quality of their school; they need a quality assurance system to provide this information.

Because: changes in legislation oblige school boards to improve their governance of schools.

2.2. If school boards improve their governance of schools, they will take measures to prevent their schools from failing.

Because: good governance of schools includes school boards' implementing quality assurance of schools, separating administration and internal supervision of schools and accountability to stakeholders.

Because: internal supervisors will use governmental regulations, inspection standards and information to control school boards.

2.3. If school boards take measures to prevent their schools from failing, these schools will provide good education.

2.3. If school boards improve their governance of schools, they will identify failing schools at an early stage.

2.4. If school boards identify failing schools at an early stage, they will take action to make sure these schools improve.

2.5. If school boards take action to make sure failing schools improve, these schools will (ultimately) provide good education.

Table A3

Assumptions on four yearly visits.

3. If all schools are visited at least once every four years, schools will provide good education.

3.1. If all schools are visited at least once every four years, the Inspectorate will have a reality check on the quality of education in schools and will prevent $s$ chools from having no inspection visit for a long period of time.

3.2. If the Inspectorate provides for a reality check on the quality of education in schools and prevents schools from having no inspection visit for a long period of time, schools will provide good education.

Table A4

Assumptions on publication of inspection information.

4. If the Inspectorate of Education publishes information about quality of schools, schools will provide good education.

4.1. If the Inspectorate of Education publishes information about quality of schools, internal supervisors, stakeholders and school boards will use this information (e.g. to monitor and control schools, to choose schools or to motivate schools to improve).

4.2. If internal supervisors, stakeholders and school boards use the inspection information, schools will be motivated to improve.

4.3. If schools are motivated to improve, they will provide for good education.

\section{References}

Ambtelijke Commissie Toezicht II. (2005). Toezicht naar naleving voor de samenleving. Den Haag: Ministerie van Binnenlandse Zaken en Koninkrijksrelaties.

Bekkers, V.J.J.M.. (2009). Sturing van het onderwijs: Over de (on) mogelijkheid van een robuuste sturingsconceptie. Nederlands Tijdschrift voor Onderwijsrecht en Onderwijsbeleid (NTOR), 1: 5-25.

Black, J., \& Baldwin, R. (2010). Really responsive risk-based regulation. Law \& Policy, 32(2), 181-213.

Department of Internal Affairs. (2005). Minder last meer effect: Zes principes van goed toezicht. Kaderstellende visie op toezicht. Den Haag: Ministerie van Binnenlandse Zaken en Koninkrijksrelaties.

Department of Education, Culture, and Science. (2005). Beleidsnotitie Governance in het Onderwijs. [Governance letter] (Kamerstukken II 2005/06, 30 183, nr. 6). Den Haag: Ministerie van Onderwijs, Cultuur en Wetenschap.

Department of Education, Culture, and Science. (2006). Toezicht in vertrouwen, Vertrouwen in toezicht, Visie op toezicht OCW; 2007-2011 [trustworthy inspections]. Den Haag: Ministerie van Onderwijs, Cultuur en Wetenschap.

Department of Education, Culture, and Science. (2007). Beleidsreactie evaluatie WOT en andere ontwikkelingen in het onderwijstoezicht. Kenmerk PEO/BEO/2007/23178. Den Haag: Ministerie van Onderwijs, Cultuur en Wetenschap.

Department of Education, Culture, and Science. (2009). Memorandum of understanding of the reenacted Supervision Act. Nr.32193, 3. Memorie van toelichting - Wijziging van de Wet op het onderwijstoezicht en enige andere wetten in verband met de invoering van geïntegreerd toezicht en de gewijzigde rol van de Inspectie van het onderwijs bij het toezichtproces - Hoofdinhoud]. Den Haag: Ministerie van Onderwijs, Cultuur en Wetenschap.

de Wolf, I. (2007). Risicoanalyse en risicomanagement bij toezichthouders. In F. L. Leeuw, J. S. Kersenboom, \& R. Elte (Eds.), Turven, tellen en toetsen, Over toezicht, inspectie, handhaving en evaluatie en hun maatschappelijke betekenis in Nederland (pp. 123-136). Den Haag: Boom Juridische uitgevers.

de Wolf, I. F., \& Verkroost, J. (2010). Evaluatie van de theorie en praktijk van het onderwijstoezicht. Enschede: Onderwijs Research Dagen.

Dutch Educational Council/Onderwijsraad. (2006). Deugdelijk toezicht. Den Haag: Onderwijsraad.

Ehren, M. C. M., Leeuw, F. L., \& Scheerens, J. (2005). On the Impact of the Dutch Educational Supervision Act; analyzing assumptions concerning the inspection of primary education. American Journal of Evaluation, 26(1), 60-76.

Ehren, M. C. M. (2006). Toezicht en schoolverbetering. Delft: Uitgeverij Eburon.
Elte, R. (2002). Historisch insigne in tijden van grote verandering. In P. Boekholt, H. van Crombrugge, N. L. Dodde, \& J. Tijssens (Eds.), Tweehonderd jaar onderwijs en de zorg van de staat (pp. 131-141). Assen: Koninklijke Van Gorcum B.

Elte, R., \& Scholtes, E. (2001). Uit de luwte, over strategische veranderingen in en rond de onderwijsinspectie 1990-2000. Utrecht: Inspectie van het Onderwijs.

Helderman, J. K., \& Honingh, M. E. (2009). Systeemtoezicht. Een onderzoek naar de condities en werking van systeemtoezicht in zes sectoren. Den Haag: Boom Juridische Uitgevers.

Honingh, M. E., \& Helderman, J. K. (2010). Voor wie of wat is systeemtoezicht zinvol? Tijdschrift voor Toezicht, 1(2), 6-26.

Hooge, E. H., \& Honingh, M. E. (2011). Goed Bestuur in het primair onderwijs; Resultaten van de nulmeting monitor Goed Bestuur PO 2010.

Inspectorate of Education. (2007). Brief aan bevoegd gezag van alle scholen (29 November 2007) over ontwikkelingen in het toezicht op het po en vo. Kenmerk: H2613235.. Utrecht: Inspectie van het Onderwijs.

Inspectorate of Education. (2009a). Toezichtkader PO/VO 2009. Inspection framework Primary and Secondary Educatation 2009]. Utrecht: Inspectie van het Onderwijs.

Inspectorate of Education. (2009b). Risk-based inspections as of 2009 in primary and secondary education. Utrecht: Inspectie van het Onderwijs.

Inspectorate of Education. (2010a). Risicoanalyse; risico's in beeld. Risk-based school inspections: Identifying risks]. Utrecht: Inspectie van het Onderwijs.

Inspectorate of Education. (2010b). The state of education in the Netherlands 2008-2009. Utrecht: Inspectie van het Onderwijs.

Inspectorate of Education. (2010c). Jaarwerkplan 2011. Annual working document]. Utrecht: Inspectie van het Onderwijs.

Inspectorate of Education. (2010d). Evaluatie risicogestuurd toezicht. Evaluation riskbased school inspections]. Utrecht: Inspectie van het Onderwijs.

Inspectorate of Education. (2010e). Toezicht op zwakke en zeer zwakke scholen; zo werkt het. Inspections of failing schools; this is how we do it]. Utrecht: Inspectie van het Onderwijs.

Janssens, F. J. G., \& de Wolf, I. (2009). Analyzing the assumptions of a policy program; an ex-ante evaluation of 'Educational Governance' in the Netherlands. American Journal of Evaluation, 30(3), 411-425.

Karstanje P. N. (1996). Beleidstheorie basisvorming; Een proeve van reconstructie. Amsterdam, SCO rapport 412.

Kerseboom, J. S., Leeuw, F. L., \& Elte, R. (2007). Een mozaïek van toezicht, inspectie, handhaving en evaluatie in tien thema. In F. L. eeuw, J. S. Kersenboom, \& R. Elte (Eds.), Turven, tellen en toetsen, Over toezicht, inspectie, handhaving en evaluatie en hun maatschappelijke betekenis in Nederland (pp. 9-25). Den Haag: Boom Juridische uitgevers. 
Koretz, D. M. (2002). Limitations in the use of achievement tests as measures of educators' productivity. The Journal of Human Resources, 37(4), 752-777.

Koretz, D. M. (2003). Using multiple measures to address perverse incentives and score inflation. Educational Measurement, 22(2), 18-26.

Leeuw, F. L. (2003). Reconstructing program theories: Methods available and problems to be solved. American Journal of Evaluation, 24(1), 5-20.

Mason, R. O., \& Mitroff, I. I. (1981). Challenging strategic planning assumptions; theory, cases and techniques. New York: John Willey \& Sons.

McNamara, G., \& O'Hara, J. (2008). The importance of the concept of self-evaluation in the changing landscape of education policy. Studies in Educational Evaluation, 34 173-179.
Smeets, G., \& Verkroost, J. (2011). Selectief en slagvaardig; werken met de WOT (20002010). Utrecht: Inspectie van het Onderwijs.

Rogers, P. J. (2000). Causal models in program theory evaluation. New Directions for Evaluation, 87, 47-55.

Teisman, G. (1992). Complexe besluitvorming. Den Haag: VUGA.

Toulmin, S. (1958). The uses of argument. Cambridge: University Press.

Toulmin, S. (1964). The uses of argument. Cambridge: University Press.

Weiss, C. H. (1997). Theory-Based evaluation: Past, present, and future. New Directions for Evaluation, 76, 41-55. 